\title{
Simulation Of Underground Liqufied Petroleum Gas (LPG) Storage In A Depleted Field
}

Donald Kuiekem ( $\sim$ kuiekemdonald@yahoo.fr)

IRGM https://orcid.org/0000-0002-4997-1655

Josephine Matateyou

IRGM

William Boroh

EGEM

Ismaila Ngounouno

Universite de Ngaoundere

\section{Research Article}

Keywords: Underground storage, gas, simulation, exhausted reservoir.

Posted Date: June 1st, 2021

DOI: https://doi.org/10.21203/rs.3.rs-481483/v1

License: (9) This work is licensed under a Creative Commons Attribution 4.0 International License.

Read Full License 


\title{
SIMULATION OF UNDERGROUND LIQUFIED PETROLEUM GAS (LPG) STORAGE IN A DEPLETED FIELD
}

\author{
Donald KUIEKEM, Oil and Gas Research Engineer, kuiekemdonald@yahoo.fr, Institute of \\ Geological and Mining Research (Cameroon). \\ Josephine MATATEYOU, Oil and Gas Research Engineer, Josephine.matateyou@gmail.com, Institute of \\ Geological and Mining Research (Cameroon). \\ William BOROH, Mining Research Engineer, williamboroh@gmail.com, School of Geology and Mining \\ (Cameroon). \\ Ismaila NGOUNOUNO, Geology Professor, ngounouno@yahoo.fr, University of Ngaoundere \\ (Cameroon)
}

\section{Résumé — Simulation du stockage souterrain de gaz dans un gisement déplété -}

Le stockage souterrain en milieu poreux offre d'énormes perspectives car il est possible de réhabiliter la formation pétrolière abandonnée en stockage de gaz naturel, de gaz de pétrole liquéfié, de carbone le dioxyde et le méthane à des fins de sécurité ou en tant que réserves stratégiques. Ce travail de simulation avec le logiciel CMG a pour objectif de mettre en évidences les principaux mécanismes d'écoulement et de conservation du gaz dans un réservoir épuisé et de déterminer les conditions générales pour un stockage optimal en identifiant et en limitant les pertes de gaz.

Mots clés: Stockage souterrain, gaz, simulation, réservoir épuisé.

Abstract — Simulation of underground gas storage in a depleted field -

Underground storage in porous media offers enormous prospects as it is possible to rehabilitate abandoned petroleum formation into storage of natural gas, liquefied petroleum gas, carbon dioxide and methane for safety purposes or as strategic reserves. This simulation using CMG software aims to highlight the main mechanisms of gas flow and conservation in an exhausted reservoir and to determine the general conditions for optimal storage by identifying and limiting gas losses.

Keywords: Underground storage, gas, simulation, exhausted reservoir.

\section{LIST OF ABREVIATIONS AND SYMBOLS}

LPG: liquefied petroleum gas

Bg: Formation gas volume factor

Bo : Formation oïl volume factor

Bw: Formation water volume factor

$\mathrm{Co}_{2}$ : Carbon dioxyde

Rs : Ratio of gas solution in oil phase

Rv: Ratio of vaporized oil in gas phase 
$\mathrm{Sg}$ : Gas saturation

So : Oil saturation

Sw : Water saturation

$\Phi$ : Porosity

\section{Introduction}

Storage of energy resources is necessary to compensate for fluctuations supply due to all kinds of hazards during production, transport and refining or its variations in consumption, which depend in particular on the meteorological conditions. It is also strategic to ensure a minimum of energy autonomy of the consuming country. Storage must be ensured at the various stages of the progress of the oil, from the production well to the point of consumption. These storages concern crude oil, fillers, intermediate cuts and finished products before shipping.

Tanks are the most widely used storage means in the petroleum industries. They can be cylindrical or spherical depending on the product to be stored. The reservoirs, generally cylindrical in shape, are of three types:

- Fixed roof tanks, used for the storage of unstabilized oil (i.e. petroleum still containing volatile hydrocarbons which can degas). There are two types of fixed roofs, conical roofs and domed roofs (spherical or ellipsoidal).

- Floating roof tanks (single deck or double decks), used for storage stabilized oil (not presenting a risk of degassing). The roof floats on the product stored and sealed with the tank dress by means of a gasket.

- Flexible tanks are another means just as tight and reliable as the previous alternatives. The capacity of this type of product is very large and can go up to $1500 \mathrm{~m} 3$. Its use tends to develop today compared to sustainable development initiatives for companies.

For the case of LPG, we distinguish:

- Cylindrical shaped bullet;

- Spherical vessel.

Underground hydrocarbons storage are define by 3 types:

- Storage in mined tunnels: By conventional means, galleries similar to mining galleries or tunnels are dug, but these galleries are closed except for the tubes which allow the circulation of the stored fluids. The excavation cost is relatively high, which makes this technique attractive only for liquid or liquefiable products.

- Salt cavern storage: The remarquable solubility of rock salt is used to dig large cavities in deep salt deposits by simply circulating fresh water. This technique can be used for all liquid, gaseous or liquefied hydrocarbons.

- Storage in aquifers and depleted fields: we reproduce a natural gas deposit by choosing a site that meets all conditions that means a sufficiently porous and permeable level, topped by a thick impermeable layer of curved shape, so that the gas is trapped as if under a bell in the upper part of the structure. Instead of being abandoned at low pressure when the hydrocarbons can no longer be exploited, the gas or oil deposit is relined to allow for cycling (injection and withdrawal) of the gas. When it is an oilfield, the gas 
withdrawn has been enriched in condensates (by vaporization under pressure at the bottom of the highest compounds of oil), which can be an additional interest for storage exploitation.

Table1. Characteristics of the different types of underground storage

\begin{tabular}{|c|c|c|c|}
\hline characteristics & Mined cavity & Saline cavity & $\begin{array}{l}\text { Storage in aquifers } \\
\text { and porous media }\end{array}$ \\
\hline Sealing & Hydrodynamics & Intrinsic & $\begin{array}{l}\text { Intrinsic (cover and } \\
\text { bottom) }\end{array}$ \\
\hline Setting up & $\begin{array}{l}\text { Excavated (machines/ } \\
\text { explosives) }\end{array}$ & Leached (fresh water) & $\begin{array}{l}\text { Natural voids (porous } \\
\text { network) }\end{array}$ \\
\hline Stored products & $\begin{array}{l}\text { Natural gas, crude and refine } \\
\text { oil and compressed air }\end{array}$ & $\begin{array}{l}\text { Liquid hydrocarbons } \\
\text { ( crude oil, naphtha, } \\
\text { LPG), compressed air } \\
\text { and hydrogen }\end{array}$ & $\begin{array}{l}\text { Natural gas ( high } \\
\text { pressure : 30bar to } \\
\text { 200bar) and } \mathrm{Co} 2\end{array}$ \\
\hline Depth & Shallow & $\begin{array}{l}\text { Variable depth (300 to } \\
200 \mathrm{~m})\end{array}$ & Depth : 500 to $3000 \mathrm{~m}$ \\
\hline Form & Horizontal development & Vertical development & $\begin{array}{l}\text { Closed structures in } \\
\text { antiform/ bell }\end{array}$ \\
\hline Dimension & $\begin{array}{l}\text { Height } 15 \text { to } 30 \mathrm{~m} \text {, width } 10 \text { to } \\
25 \mathrm{~m} \text {, length } 100 \text { to } 1000 \mathrm{~m} \text {, } \\
\text { section } 80 \text { to } 650 \mathrm{~m}^{2}\end{array}$ & $\begin{array}{l}\text { Height } 100 \text { to } 300 \mathrm{~m} \text {, } \\
\text { diameter } 30 \text { to } 70 \mathrm{~m}\end{array}$ & $\begin{array}{l}\text { Natural network of } \\
\text { kilometer extension }( \\
\text { similar to natural } \\
\text { hydrocarbon } \\
\text { reservoirs) }\end{array}$ \\
\hline Volume & $\begin{array}{l}\text { Volume } 100000 \text { to } 500000 \mathrm{~m}^{3} \\
\left(10000-1000000 \mathrm{~m}^{3}\right)\end{array}$ & $\begin{array}{l}\text { Volume } 150000 \text { to } 650 \\
000 \mathrm{~m} 3\end{array}$ & $\begin{array}{l}\text { Useful volume } 0.5 \text { to } \\
4 \text { billion } \mathrm{Nm}_{3} \text { plus a } \\
\text { cushion gas }\end{array}$ \\
\hline Access & $\begin{array}{l}\text { Physical access by tunnel or } \\
\text { shaft }\end{array}$ & $\begin{array}{l}\text { Only access to drilling } \\
\text { (leaching \& } \\
\text { exploitation) }\end{array}$ & $\begin{array}{l}\text { Several drillings } \\
\text { (exploration, } \\
\text { exploitation \& } \\
\text { follow-up) }\end{array}$ \\
\hline Recognition & $\begin{array}{l}\text { Drilling \& direct observations } \\
\text { during excavation }\end{array}$ & $\begin{array}{l}\text { Drilling and indirect } \\
\text { methods (3D image by } \\
\text { sonar leaching) }\end{array}$ & $\begin{array}{l}\text { Drilling \& indirect } \\
\text { methods, geophysics, } \\
\text { logs, tests }\end{array}$ \\
\hline Operation & $\begin{array}{l}\text { Bottom pumps, water curtain, } \\
\text { monitoring, piezometric } \\
\text { monitoring }\end{array}$ & $\begin{array}{l}\text { No bottom equipment, } \\
\text { creep monitoring, } \\
\text { traps, brine } \\
\text { management }\end{array}$ & $\begin{array}{l}\text { No background } \\
\text { equipment, interface } \\
\text { tracking, peripheral } \\
\text { control. }\end{array}$ \\
\hline
\end{tabular}

Historically, depleted gas reservoirs have been the most important and commonly used formations for natural gas storage. A depleted field is generally the most appropriate option 
because it has proven characteristics for storing gas. There is a considerable level of data already available on the geological, structural and petrophysical characteristics of the primary production. Commercially, depleted reservoirs can provide very good storage efficiency, volume and peak performance in terms of injection rates/ or gas withdrawal.

\section{Methodology}

To build the model, we use the software CMG (Computer Modelling Group) especially Builder and Imex interfaces. The following parameters were simplified:

- The action of the temperature in the reservoir is neglected;

- The rock compressibility is constant;

- The injection and production parameters are set at the limits;

- The period intervals of operations are annual;

- The injected water is non-saline;

- The injected gas is composed of $12 \%$ ethane, $38 \%$ of propane and $50 \%$ of butane.

\section{a) The model design}

We build a reservoir model with a normal fault composed of 3 layers of constant porosity at $30 \%$. The fluid flow model here is a "black oil" that means the fluid flow equations are partial differential equations in contrast of the compositional formulation. The equations for an extended black oil model are:

$$
\begin{gathered}
\frac{\partial}{\partial t}\left[\varphi\left(\frac{S_{O}}{B_{O}}+\frac{R_{V} S_{g}}{B_{g}}\right)\right]+\nabla \cdot\left(\frac{1}{B_{O}} \overrightarrow{u_{g}}+\frac{R_{V}}{B_{g}} \overrightarrow{u_{g}}\right)=0 \\
\frac{\partial}{\partial t}\left[\varphi\left(\frac{S_{w}}{B_{w}}\right)\right]+\nabla \cdot\left(\frac{1}{B_{w}} \overrightarrow{u_{w}}\right)=0 \\
\frac{\partial}{\partial t}\left[\varphi\left(\frac{R_{S} S_{O}}{B_{O}}+\frac{S_{g}}{B_{g}}\right)\right]+\nabla \cdot\left(\frac{R_{S}}{B_{O}} \overrightarrow{u_{O}}+\frac{1}{B_{g}} \overrightarrow{u_{g}}\right)=0
\end{gathered}
$$

Where $\phi$ is the porosity, $\mathrm{Sw}$ is the water saturation, So, $\mathrm{Sg}$ are the liquid and vapor phase saturations in the tank. Oil and gas at the surface (standard conditions) could be produced from both liquid and vapor phases. This is characterized by the following quantities:

- Bo is a factor of the volume of formation oil (ratio of a certain volume of tank liquid to the volume of oil under standard conditions obtained from the same volume of tank liquid);

- $\quad \mathrm{Bw}$ is a factor of the volume of formation water (ratio of the volume of water at tank conditions to the volume of water at standard conditions);

- $\mathrm{Bg}$ is a factor of the volume of formation gas (ratio of a certain volume of tank vapor to the volume of gas under standard conditions obtained from the same volume of tank vapor);

- Rs is the ratio of an oily phase gas solution (ratio of the volume of gas to the volume of oil at standard conditions obtained from a certain amount of liquid phase at tank conditions); 
- $\mathrm{Rv}$ is a ratio of vaporized oil to gas phase (ratio of the volume of oil to the volume of gas at standard conditions obtained from a certain amount of vapor phase at tank conditions).

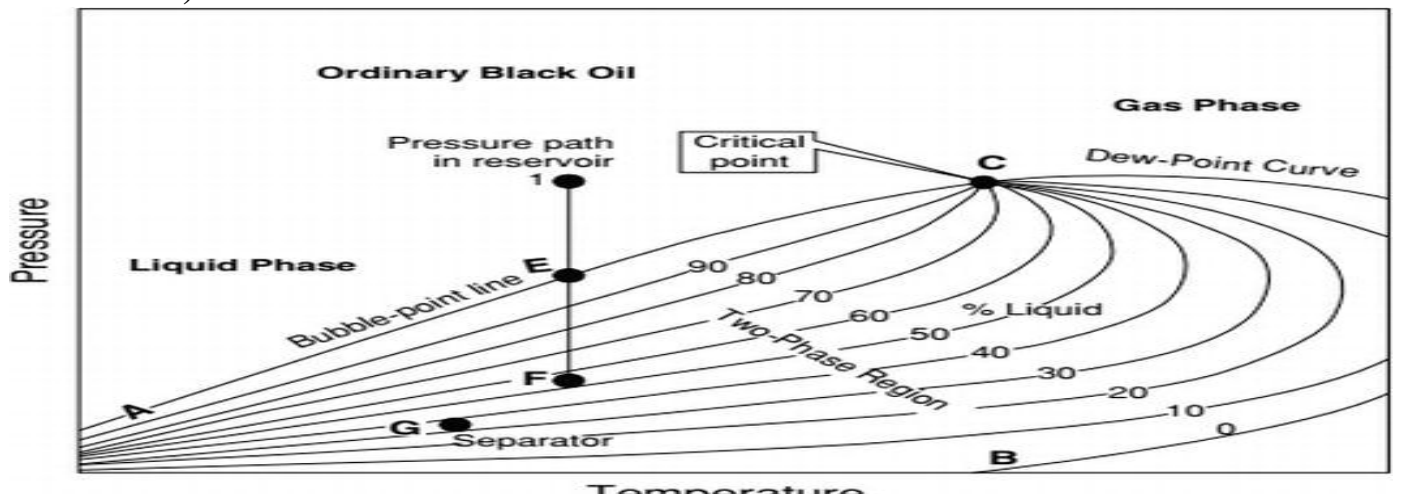

Figure 1. Typical phase diagram of black oil.

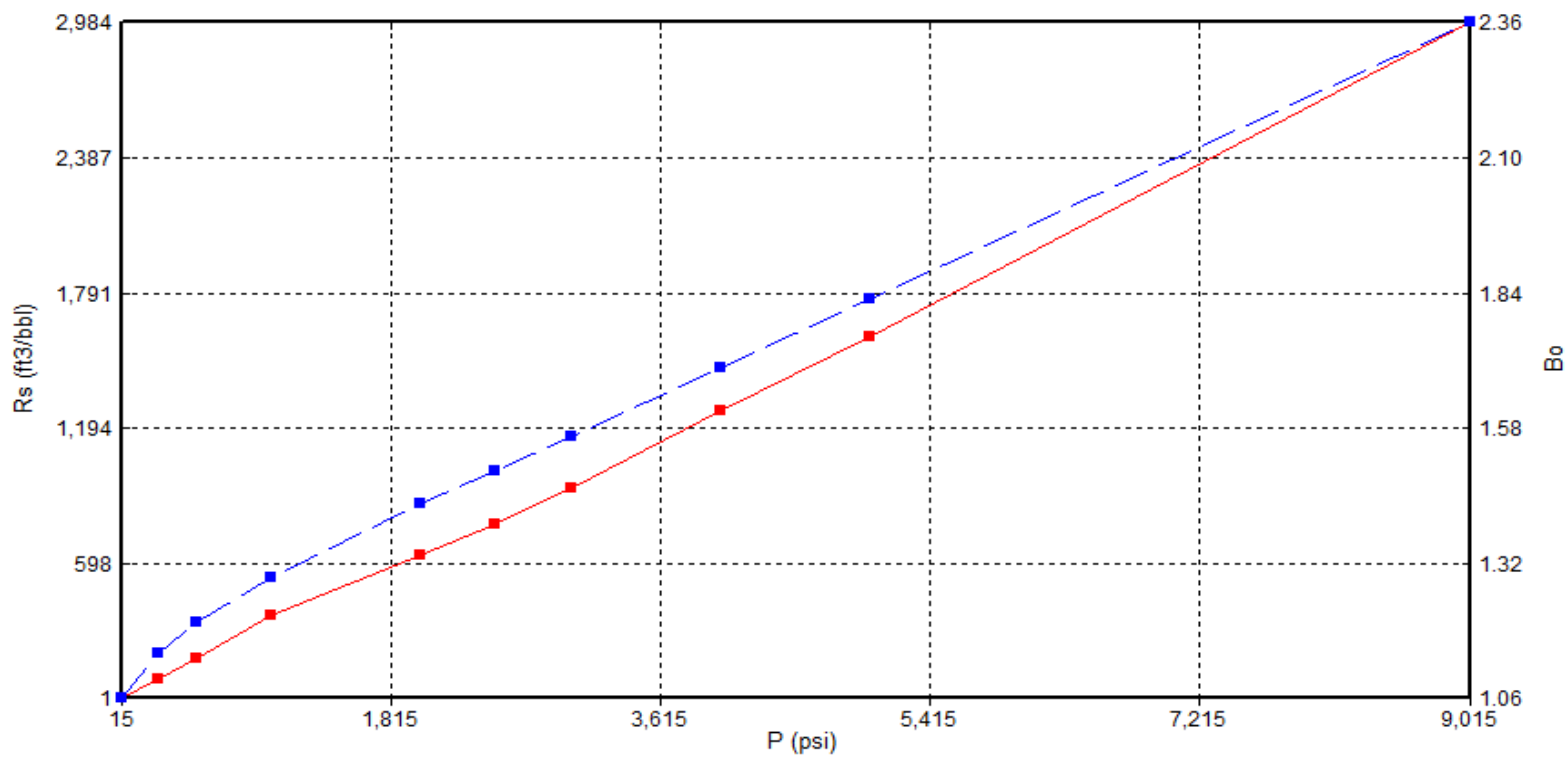

Figure 2. Relationship between solution gas ratio, formation oil volume factor and pressure

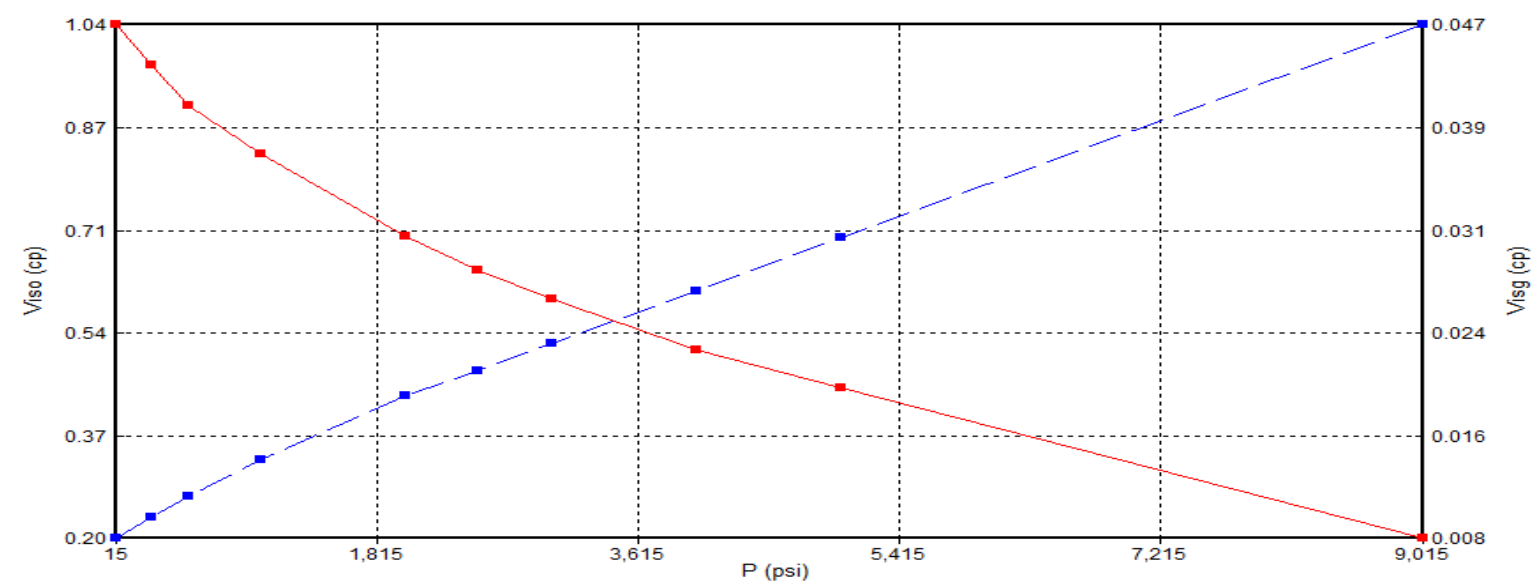


Figure 3. Relationship between oil and gas viscosity as function of pressure

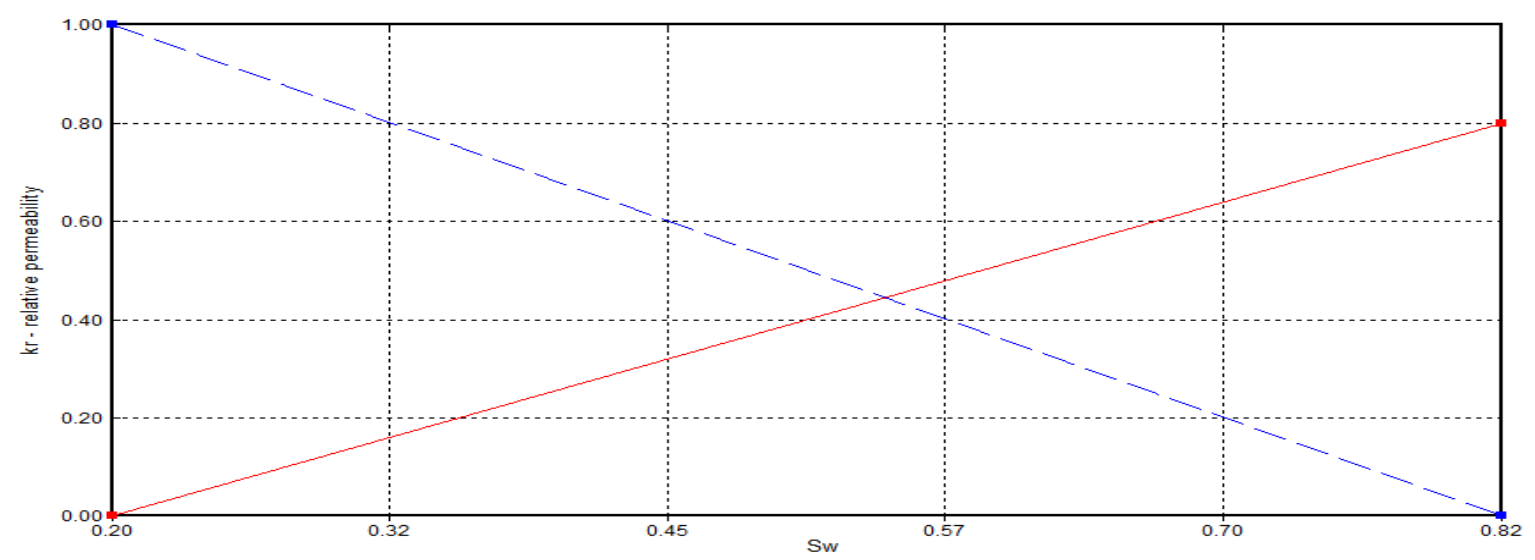

krwvs Sw
krow vs Sw

Figure 4. Relationship between relative oil and water permeability as function of water saturation

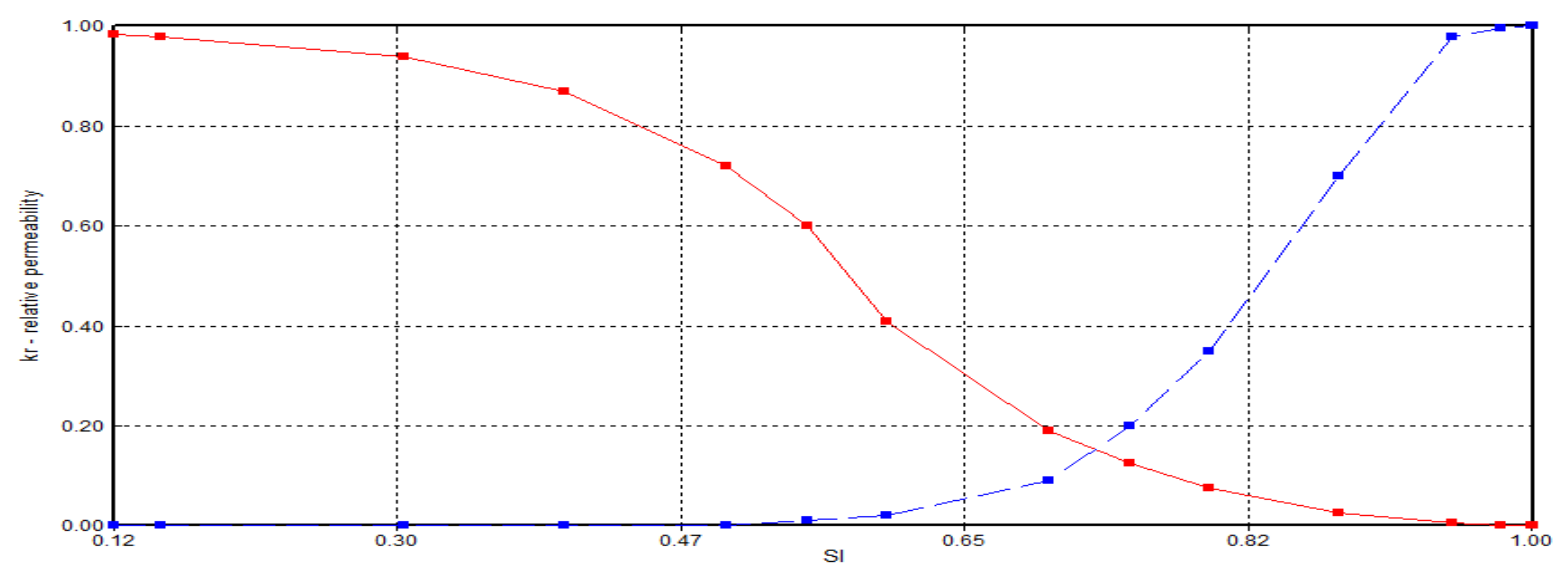

krg vs SI
krog vs SI

Figure 5. Relationship between relative permeability of oil and gas as function of water saturation

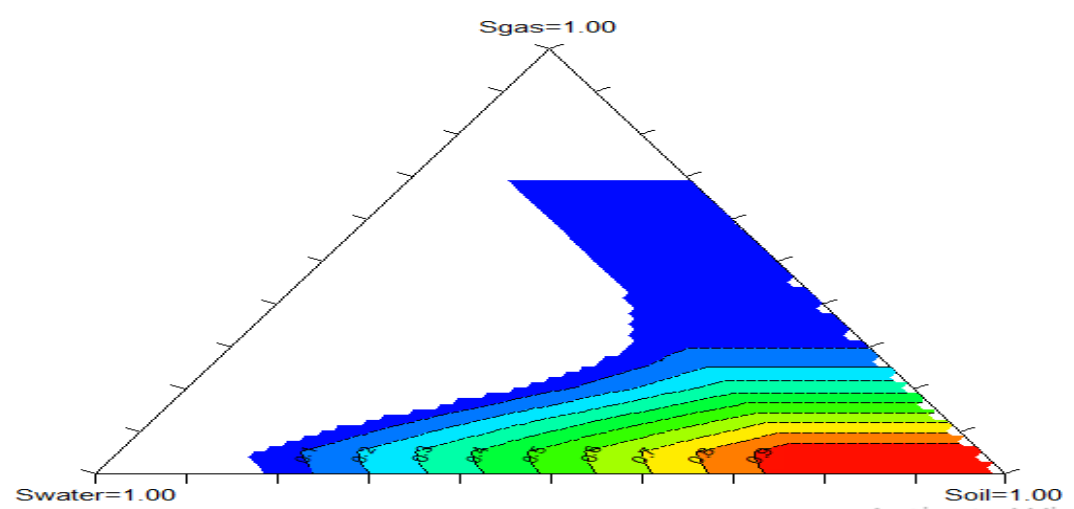


Figure 6. Relationship between water, oil and gas saturation.

\section{b) Primary and secondary recovery}
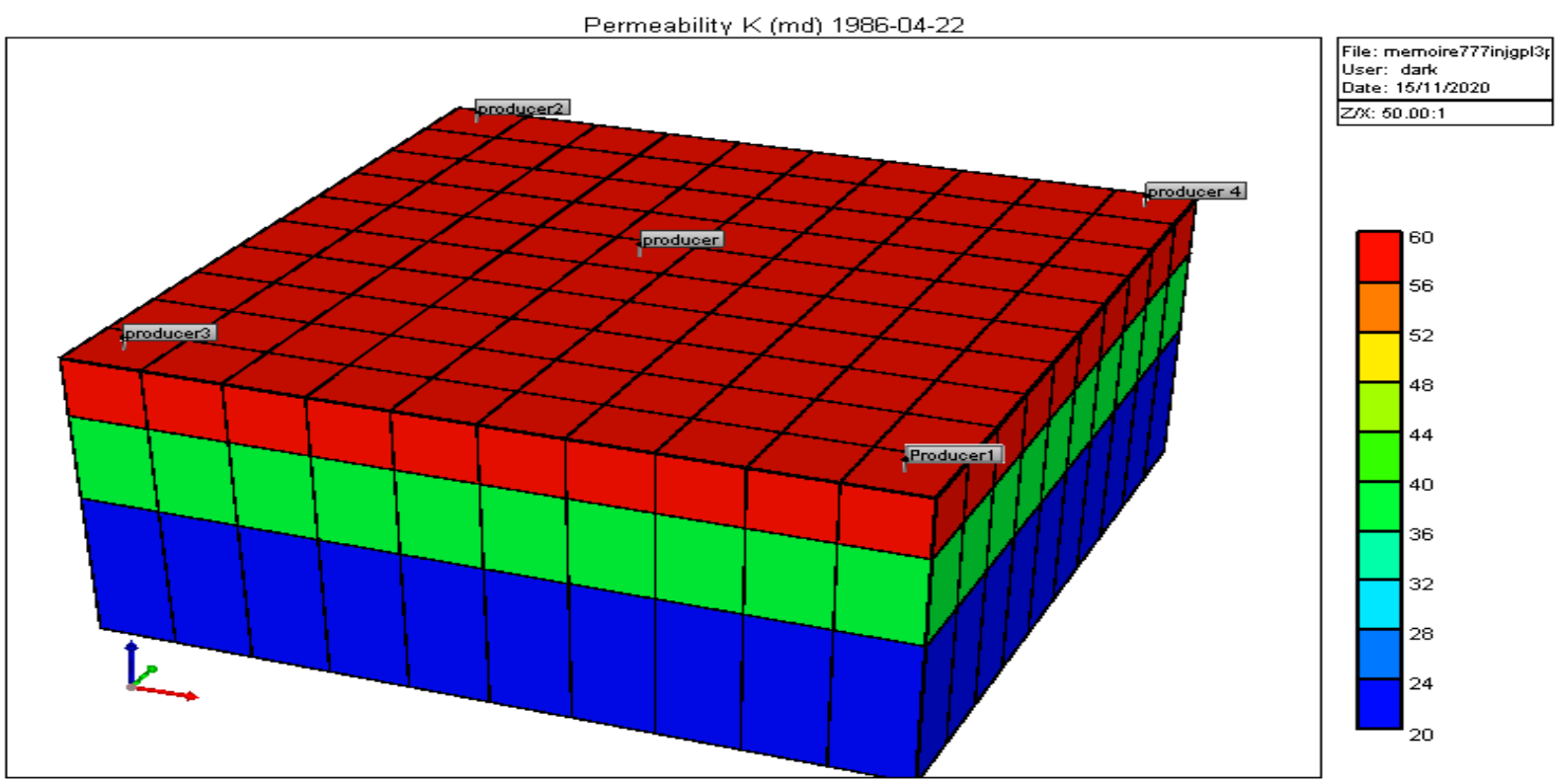

Figure 7. Distribution of permeability along the vertical
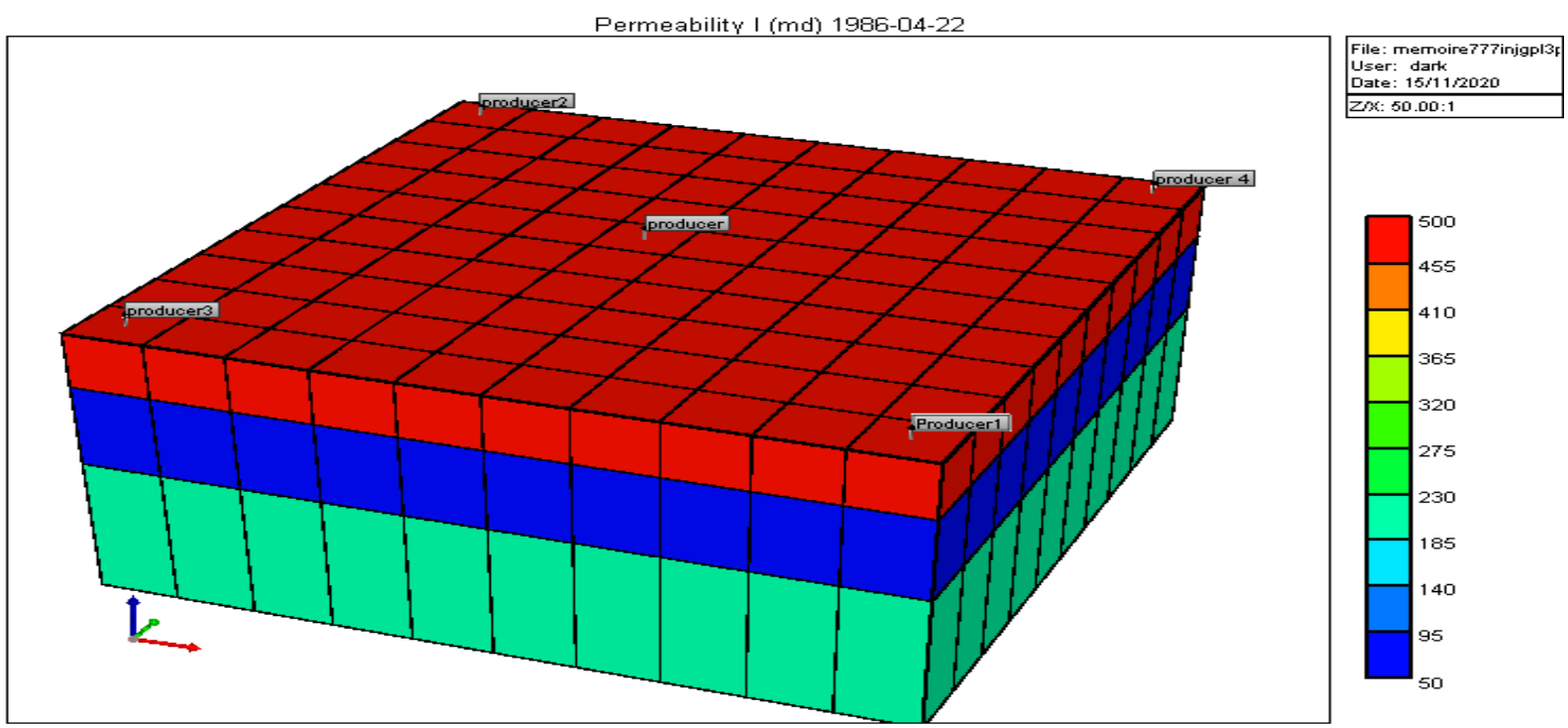

Figure 8. Distribution of permeability according to layers

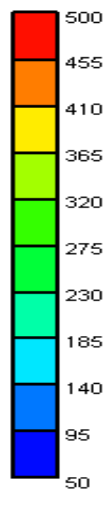




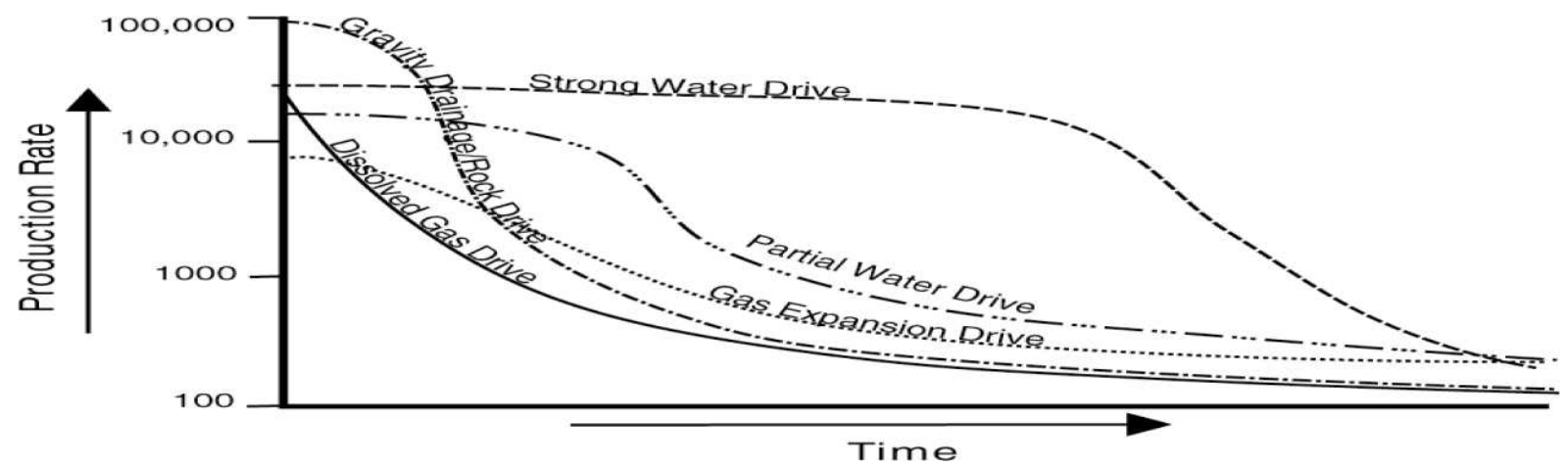

Figure 9. Declination curves according to the drive mechanism

Table 2. Reservoir parameters

\begin{tabular}{|l|l|}
\hline Densité de l'huile & $46.244 \mathrm{lbm} / \mathrm{ft}^{3}$ \\
\hline Densité du gaz & $0.0647 \mathrm{lbm} / \mathrm{ft}^{3}$ \\
\hline Densité de l'eau & $62.238 \mathrm{lbm} / \mathrm{ft}^{3}$ \\
\hline Profondeur de contact eau-huile & $9500 \mathrm{ft}$ \\
\hline Profondeur de contact gaz-huile & $7000 \mathrm{ft}$ \\
\hline Compressibilité de la roche & $3.0 \mathrm{E}-6$ \\
\hline Pression de point de bulle & $4014.7 \mathrm{Psi}$ \\
\hline Pression du réservoir & $4805 \mathrm{KPa}$ \\
\hline Volume d'huile initialement en place & $0.25858 \mathrm{E}+09 \mathrm{STB}$ \\
\hline Volume de gaz initialement en place & $0.32839 \mathrm{E}+12 \mathrm{SCF}$ \\
\hline Volume d'eau en place & $0.10564 \mathrm{E}+09 \mathrm{STB}$ \\
\hline Volume de pores d'hydrocarbures & $433591 \mathrm{M}$ RBBL \\
\hline Volume total des pores & $541989 \mathrm{M} \mathrm{RBBL}$ \\
\hline
\end{tabular}

The primary and secondary recovery start in 1986 and end in 2000. Initially in the reservoir, there is no free gas due to the high bubble pressure in the reservoir.

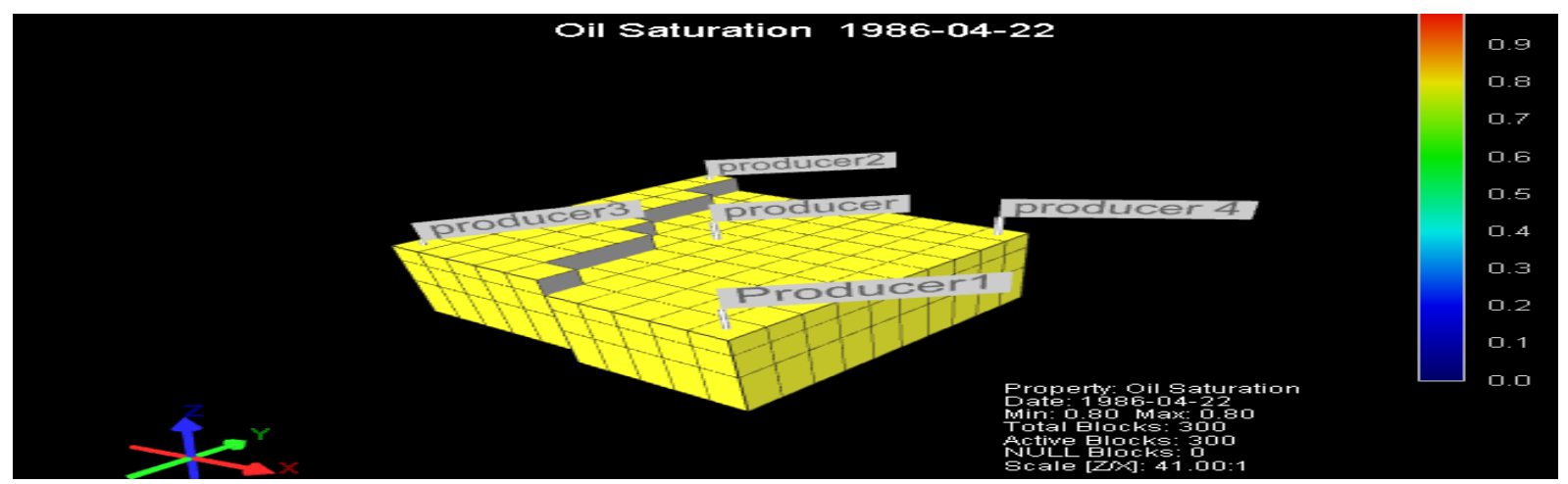

Figure 10. Oil initial saturation 


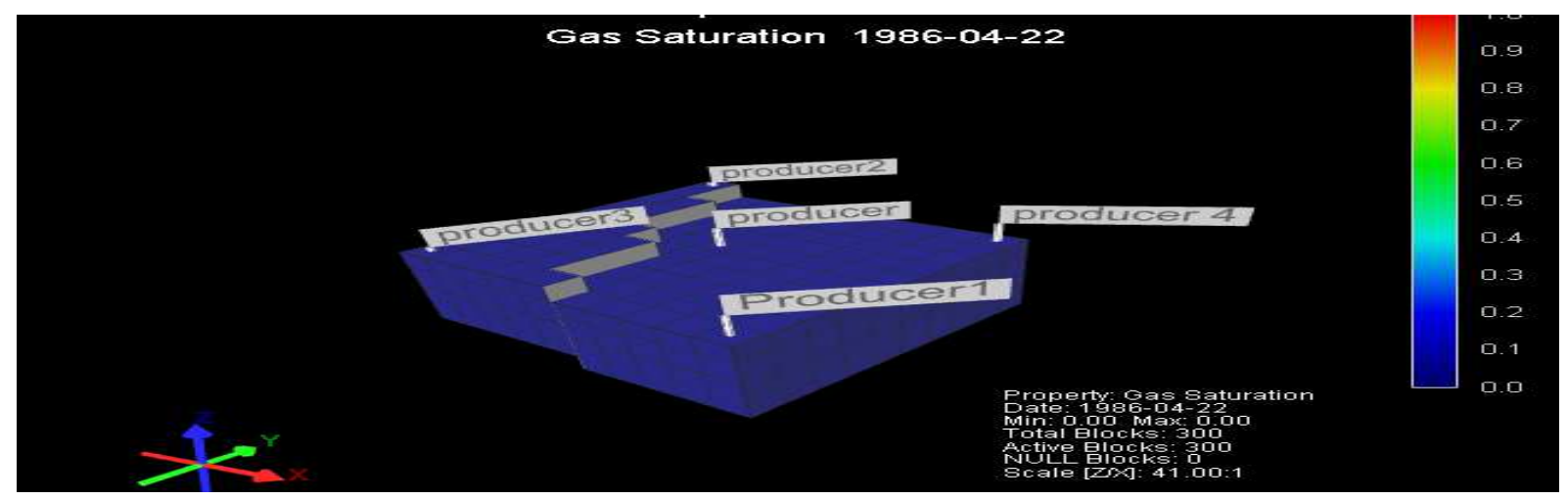

Figure 11. Initial gas saturation

\section{c) Gas injection, storage and production}

After the secondary recovery, a recovery of about 40 to $70 \%$ is possible so that we can start injecting LPG. The base gas can include both native and injected gas. This is the volume that must be left in the underground storage to provide the required pressurization so that the remaining gas can be delivered at a reasonable rates while the amount of gas injected and withdrawn during normal storage cycle is called working gas (70\%). The formation of a gas bubble ensures that the pressed-in amount of gas is able to displace the edge water, and thereby also that the gas-water front and the position of the gas-water contact actually change move. The gas-water displacement as well as the movement and position gas-water front is discuss in detail with the "displacement theory" of Cover Buckley-Leverett. The formation of a gas bubble occurs in three phases, as in the one below Figure 12 is shown.

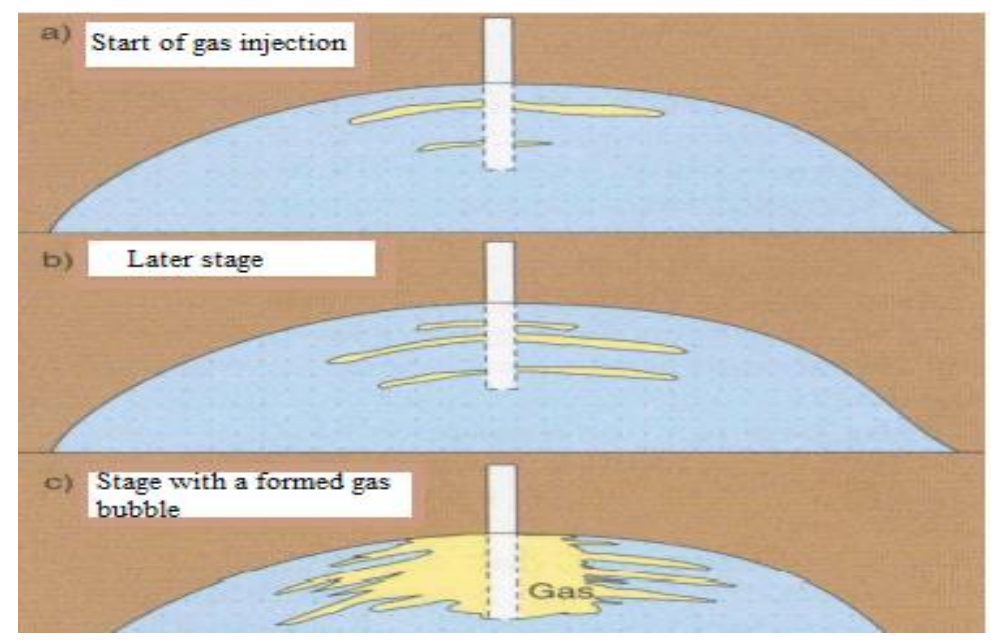

Figure 12. Formation of a gas bubble; de Muller-Kirschbauer; [18]; Chapter 6; Slide 42

To identify the gas conservation mechanism underground and to identify the gas losses during his withdrawal, we planned the operations like in Table 3.

Table 3. Schedule of injections, rest and production operations.

\begin{tabular}{|l|l|}
\hline périods & opérations \\
\hline $2000-2010$ & Gas injection (4 Wells) \\
\hline $2010-2015$ & Rest and observation of the reservoir \\
\hline
\end{tabular}




\begin{tabular}{|l|l|}
\hline $2015-2020$ & Production From the central well \\
\hline $2020-2030$ & Periodic production of the central well (50\%) \\
\hline $2030-2035$ & Injection from Gas wells 1.3.4 and production from central well \\
\hline $2035-2036$ & Production from central well \\
\hline $2036-2040$ & Production and periodic injection from central well \\
\hline $2040-2042$ & Central production \\
\hline $2042-2045$ & Rest \\
\hline $2045-2050$ & Gas injection by the 4 wells \\
\hline $2050-2053$ & Production by the 4 Wells \\
\hline
\end{tabular}

Producer 2 is closed after primary recovery because its position near the fault limits its connection with the blocks which leads errors during simulation.

\section{Results and Discussion}

\section{a) Primary recovery}

During the natural depletion of the reservoir, a cumulative production of oil of 28871 MSTB, gas 264779 MMSCF and water 35.336 MSTB is recorded, which makes 229684 MSTB of oil, $63473 \mathrm{MMSCF}$ of gas and $105603 \mathrm{MSTB}$ of water remaining in the reservoir. The percentage of hydrocarbon recovery is on average $46 \%$ (12\% oil and $80 \%$ gas). The duration is 11 years and we note that the reservoir pressure decreases significantly with the bubble pressure during the production. A significant increase of gas saturation in the reservoir is observed.

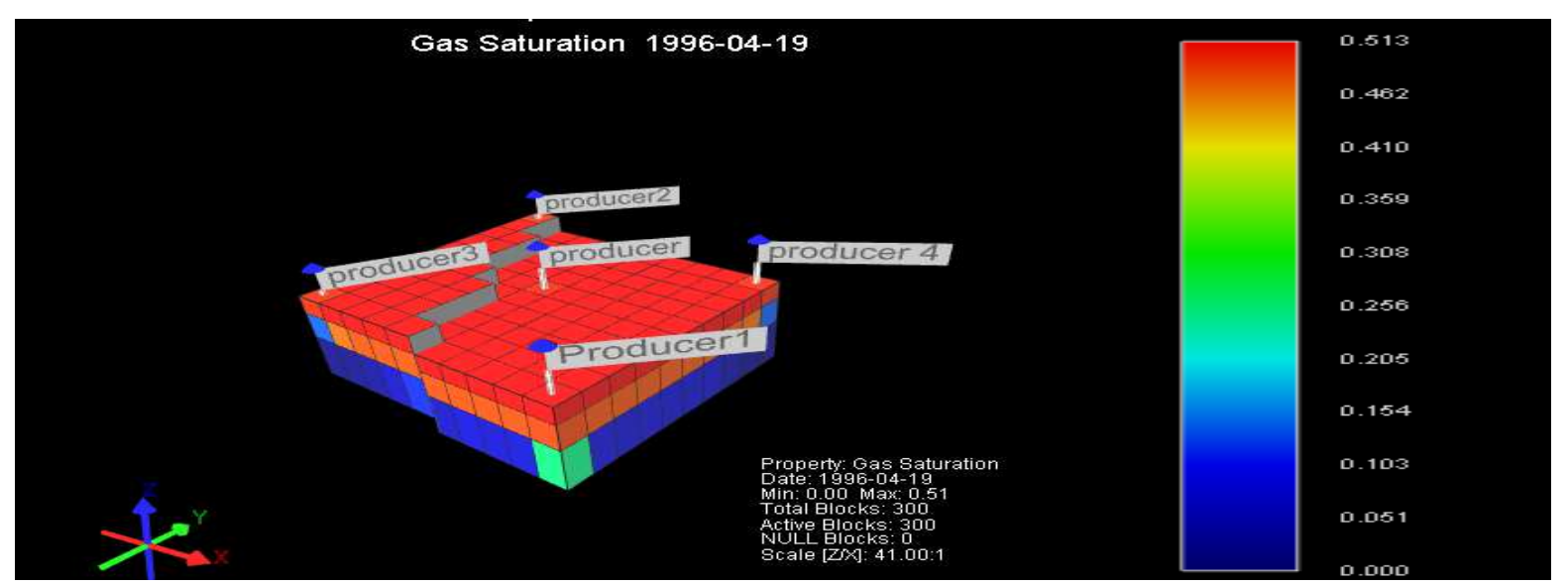

Figure 13. Distribution at the end of the primary recovery of gas saturation 


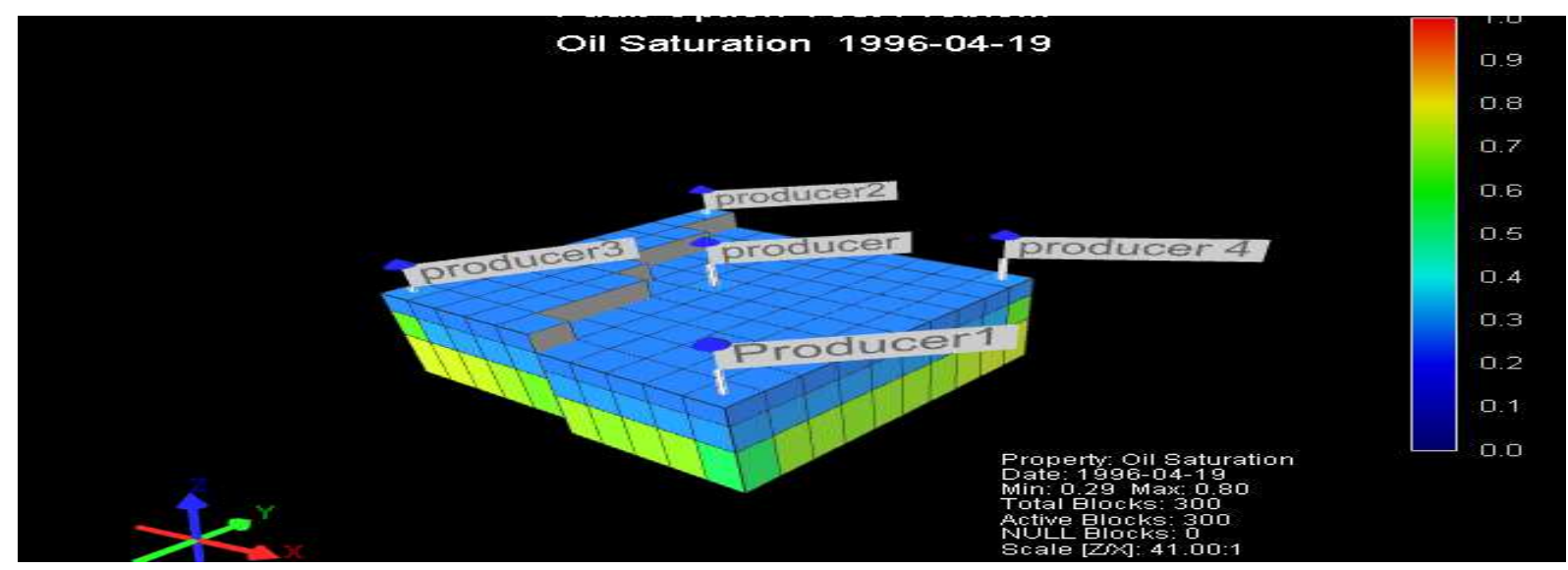

Figure 14. Oil saturation at the end of primary recovery

\section{b) Secondary recovery}

After the primary recovery, the deposit still has $54 \%$ of hydrocarbons. In order to deplete it, we inject water through 'producer3 and 4' to ensure a symmetrical sweep of the oil towards 'producer'. The injection of water into the reservoir leads to a rapid decrease in gas saturation in the reservoir. The duration is 5years and 3090 MMSTB of water was injected for an average recovery of $64 \%$ hydrocarbons that is $18 \%$ more than the primary recovery ( $41 \%$ oil and $81 \%$ gas).

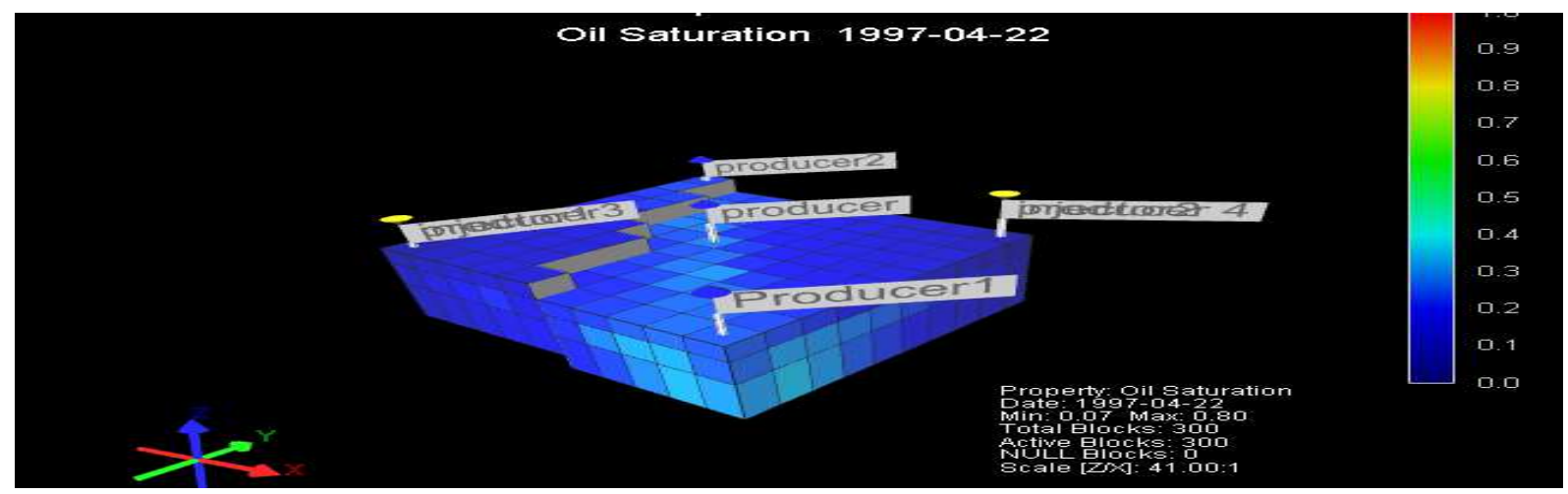

Figure 15. Oil sweeping by water

- Machine learning modeling of gas phase expansion volume determination during primary and secondary recovery

The goal is to determine through a computer model, the variation of gas saturation as function of the evolution of water saturation, oil saturation and reservoir pressure during primary and secondary recovery. The algorithm used is the neural network (Bowie, 2018) via the "Neural Net Fitting" module on Matlab 2019.

- The training data used to model the magnitude up to 70\%;

- Test data to check the robustness of the model at 20\%;

- Validation data to confirm authenticity equivalent to $10 \%$.

The following graphs in Figure 16 shows the different scores obtained during the validation of the model. 

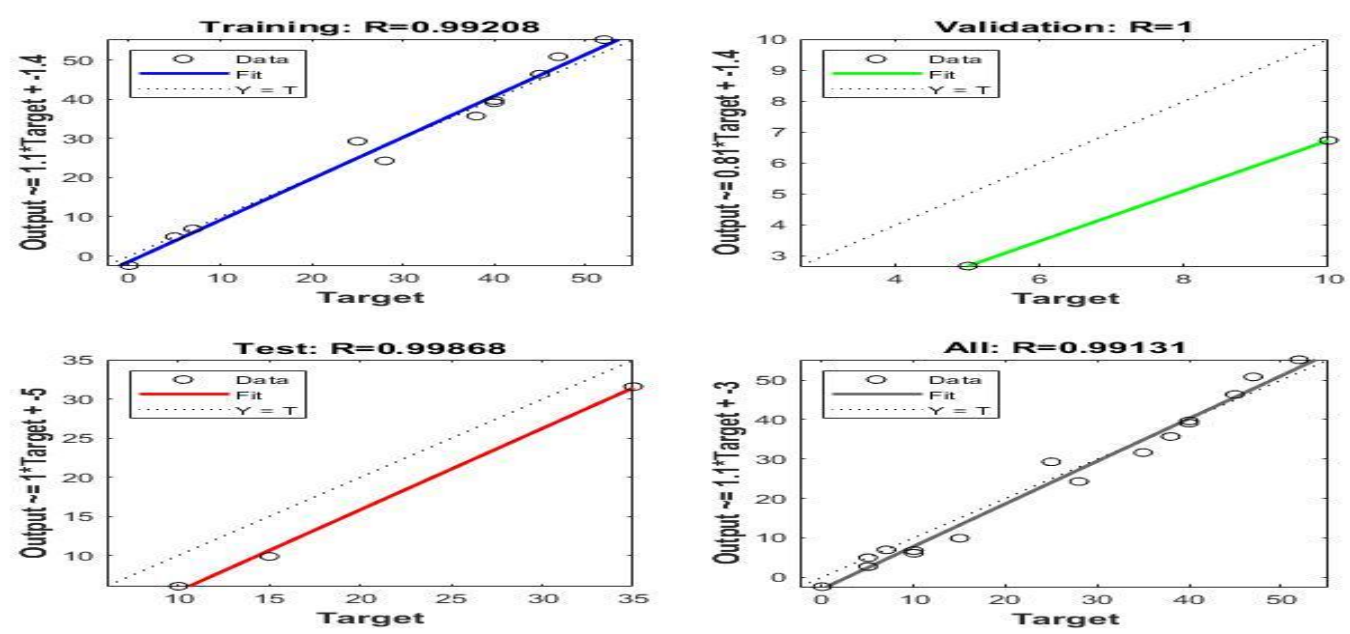

Figure 18. Validation of the computer model

\section{c) Gas injection, storage and production}

The reservoir having produce $64 \%$ of its hydrocarbons reserve, the volume extracted is estimated at 108.6 MMSTB of oil and $286288 \mathrm{MMSCF}$ of gas. The volume of water injected is 3092 MMSTB and produced is 2708 MMSTB then the average storage capacity of the reservoir is $284593 \mathrm{MMSCF}$ at normal pressure conditions. It is possible to inject more, taking into account the gas compressibility and the reservoir elasticity. Over pressurize the reservoir will increase the deliverability but could damage the stability of the reservoir and create cracks in the cap rock.

Storage capacity = Quantity of hydrocarbons produced + Quantity of water produced -

Quantity of injected water

- 2000-2010: Gas injection (4 wells)

After water injection, an increase in reservoir pressure is observed. The difference between the pressure distribution after water and injection is that the water injection was done with diagonally wells from which we observe an increasing evolution of pressure of the injectors towards the center of the model by taking into account the mobility of water while the gas injection was done by 4 wells which results in a homogeneous distribution of the pressure. The gas saturation before and after injection does not vary and we can give two hypothesis:

- The injected gas will dissolve in the residual oil

- $\quad$ The LPG will remain in liquid phase and the simulator consider it like oil. 


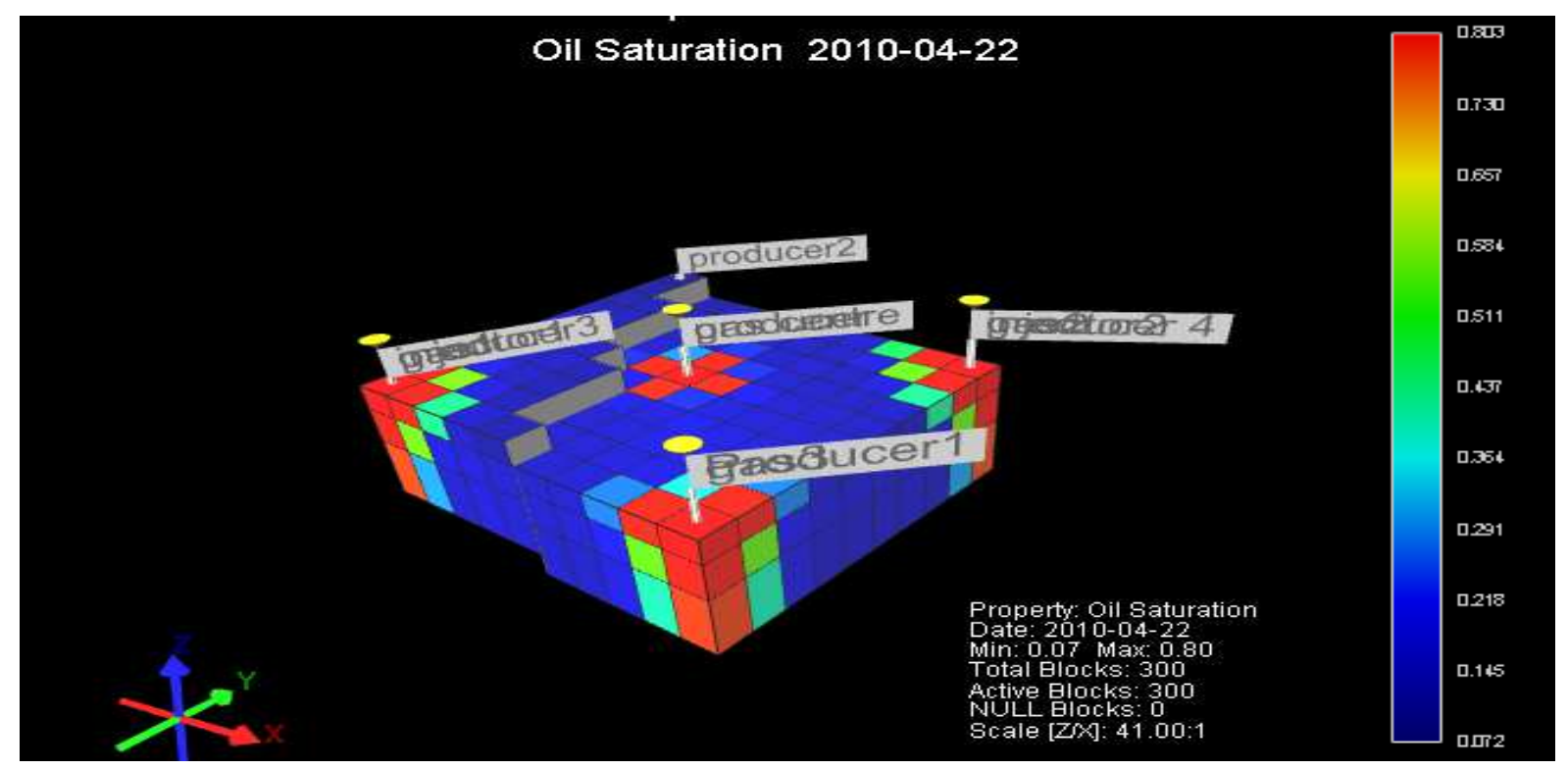

Figure 19. Oil saturation after injection.

- 2010-2015: Rest and observation of the reservoir

During the resting phase of the model we observe no change in pressure, bubble pressure and gas saturation but a slow increase in oil saturation is observed, which can corresponds to a dissolution of the gas injected into oil phase. In order to release the gas if in solution, it will be necessary to create a depressurization in the reservoir in order to make the bubble pressure drop.

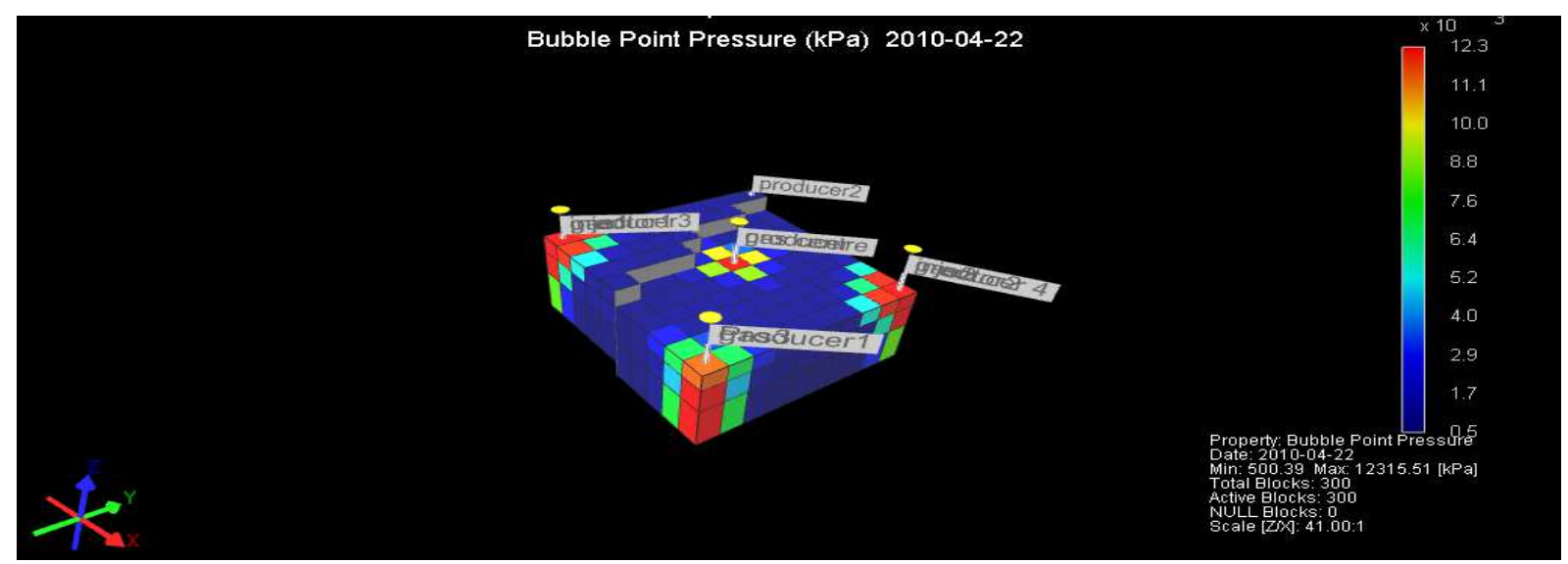

Figure 20. Bubble pressure distribution after gas injection

- 2015-2020: Production by the central well

To depressurize the model, we open the central well and oil migrate to the depressurization zone. The production of the central well has led to a drop in bubble pressure in the oil saturated zones and we observe a strong release of gas in solution. 


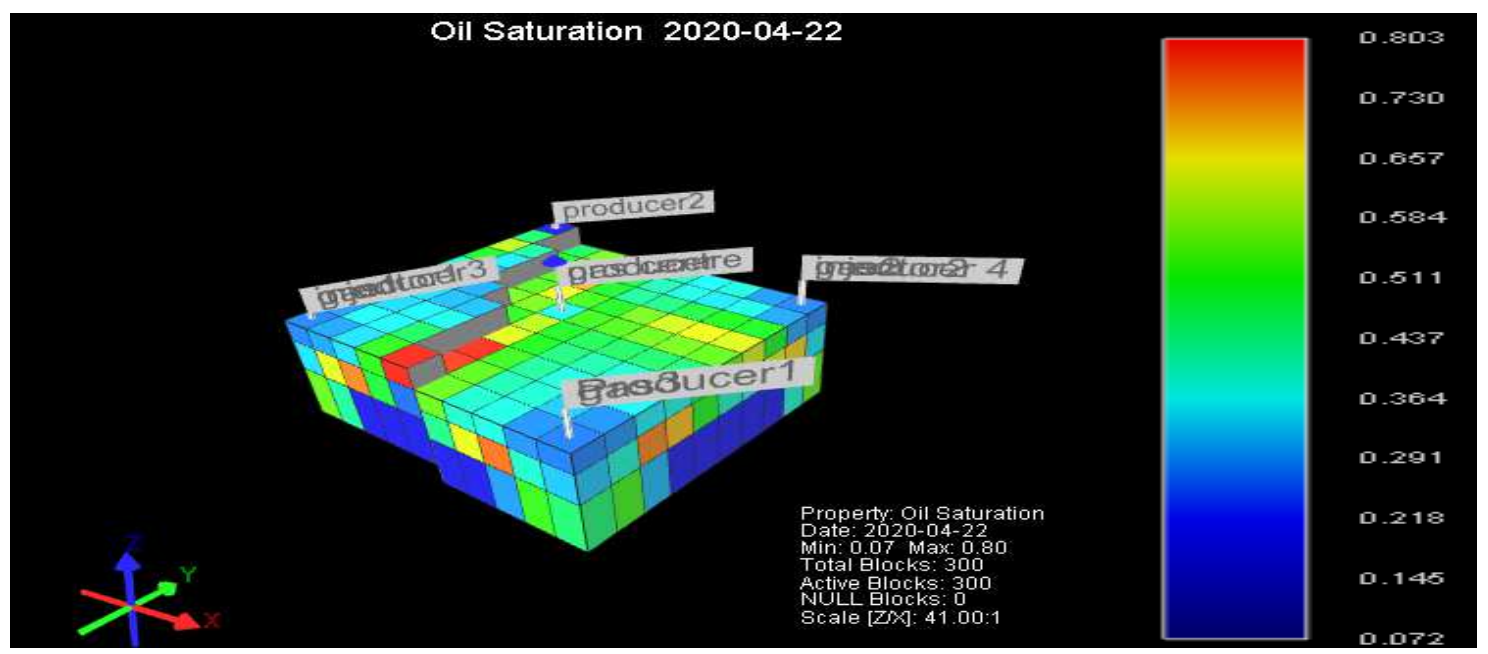

Figure 21. Oil saturation in 2020

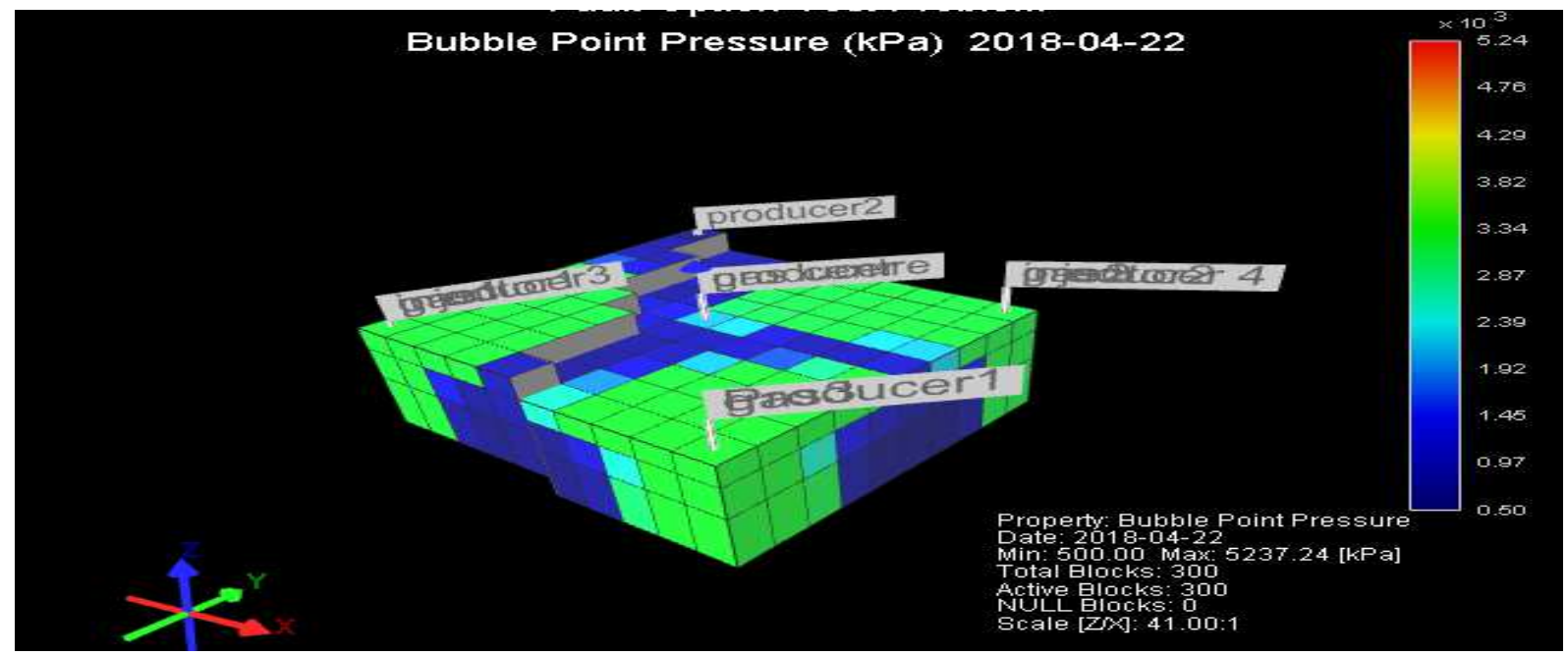

Figure 22. Bubble pressure distribution in 2018

- 2020-2030: Periodic production of the central well (50\%)

In order to maintain the gas release, we keep the central well open at the frequency of $50 \%$ per year. During this period we observe a decrease in oil saturation. We note an expansion of fre gas in the upper layers of the model. We have therefore moved from an initial conditions without free gas to a model with free gas.

- 2035-2036: Production by central well

The bubble pressure that had increased during the previous period falls back, which leads to a release of gas and improves gas saturation.

- 2036-2040: Production and periodic injection from central well

In 2040, follow a periodic injection and production from the central well about 50\% each, an increase in gas saturation and a considerable expansion of the gas at the surface is observed. Oil continues to accumulate in the lower layers particularly those where the central well is located. 


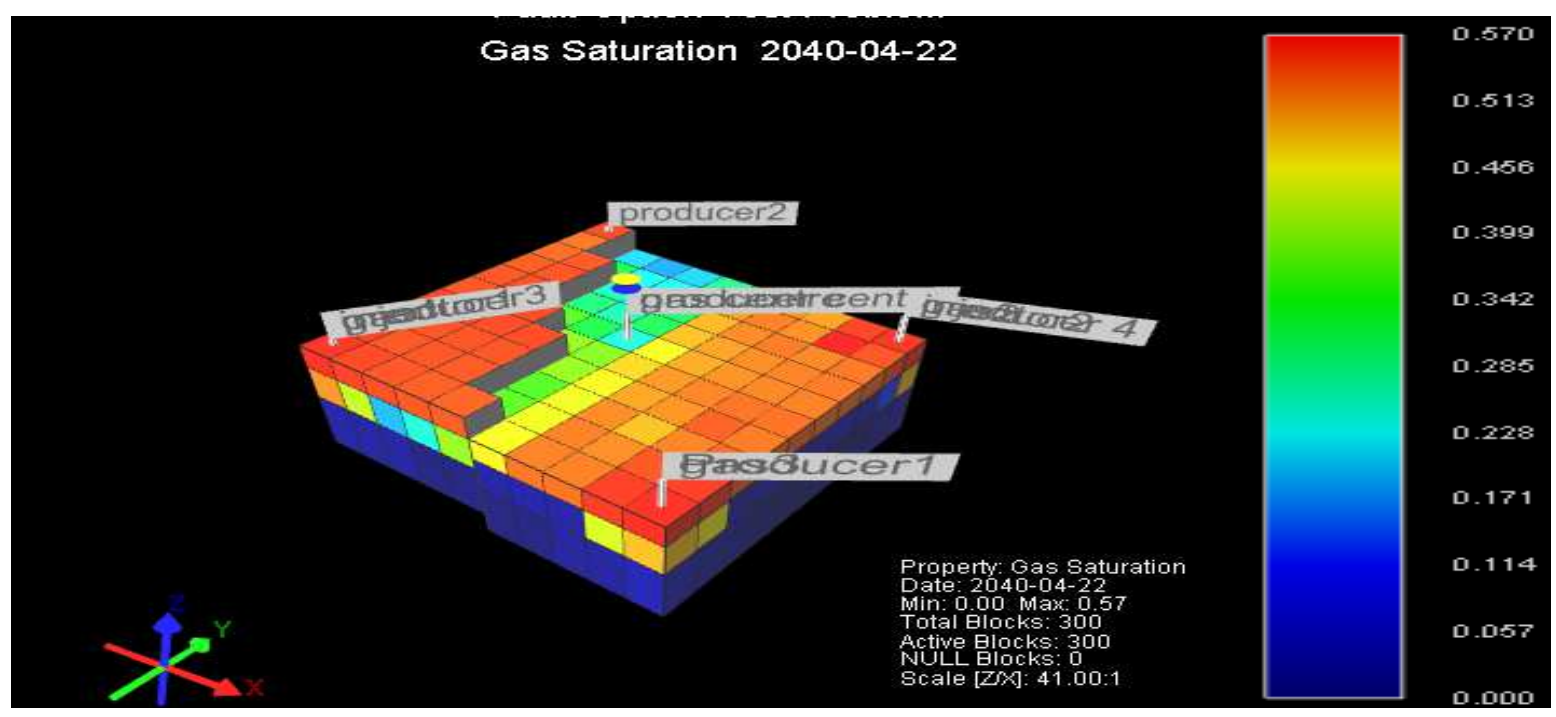

Figure23. Gas saturation in 2040

- 2040- 2045: Central production and rest

The pressure drop caused by the production from the central well. The aim of this second resting phase is to observe if the gas expansion will be slowed down. The observation is the opposite of our expectations and oil migrate from the lower layers to surface where it changes phase.

- 2045-2050: Gas injection by the 4 wells

We proceed to a second injection phase to observe if injected gas will still dissolve in the oil and how free gas will react. The injection leads to an increase of pressure in the reservoir, which facilitates the dissolution of free gas in oil. The increase of the bubble pressure in the reservoir is more important at the upper layer. It will limit the free gas expansion and cause a short decrease of gas saturation. Contrary of the first injection phase, the evolution of the bubble pressure is no longer localized at the level of the injectors.

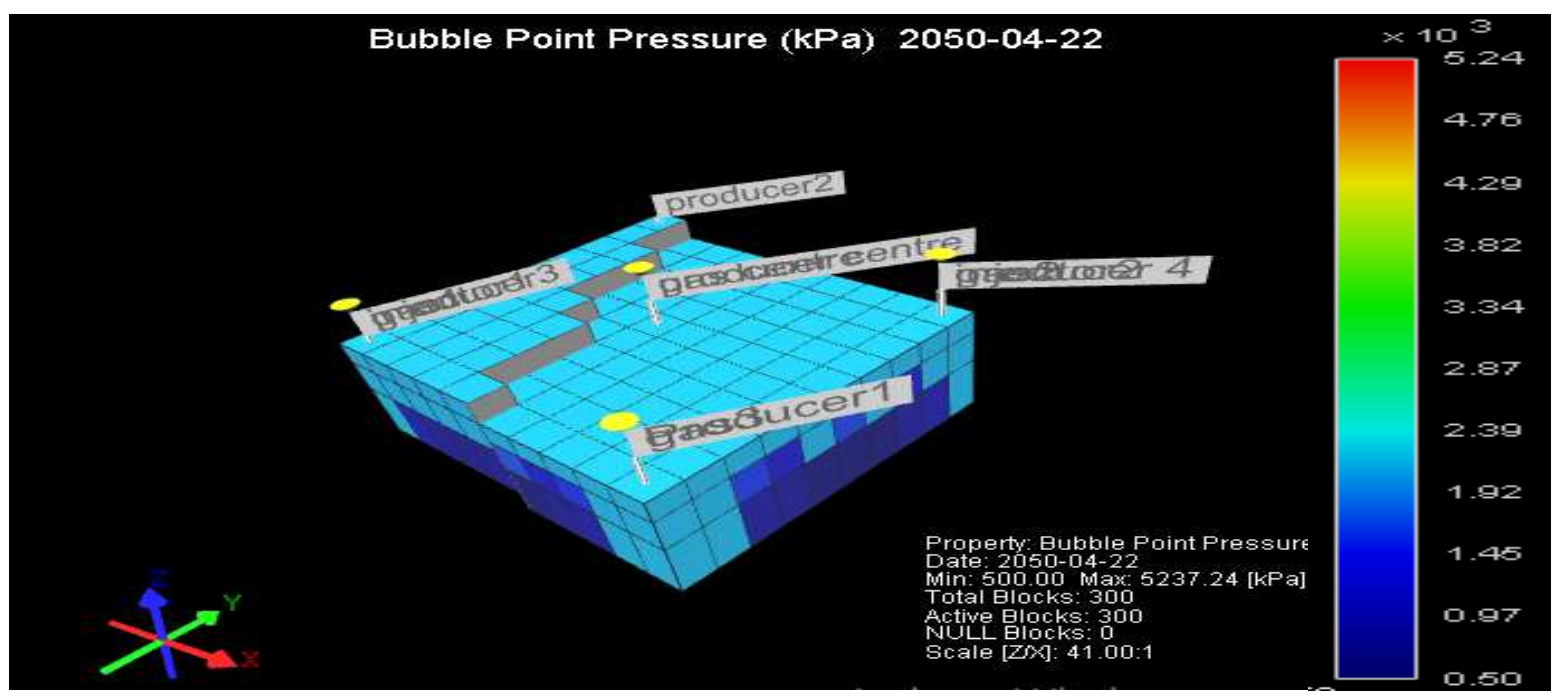

Figure 24. Distribution of bubble pressure in 2050 


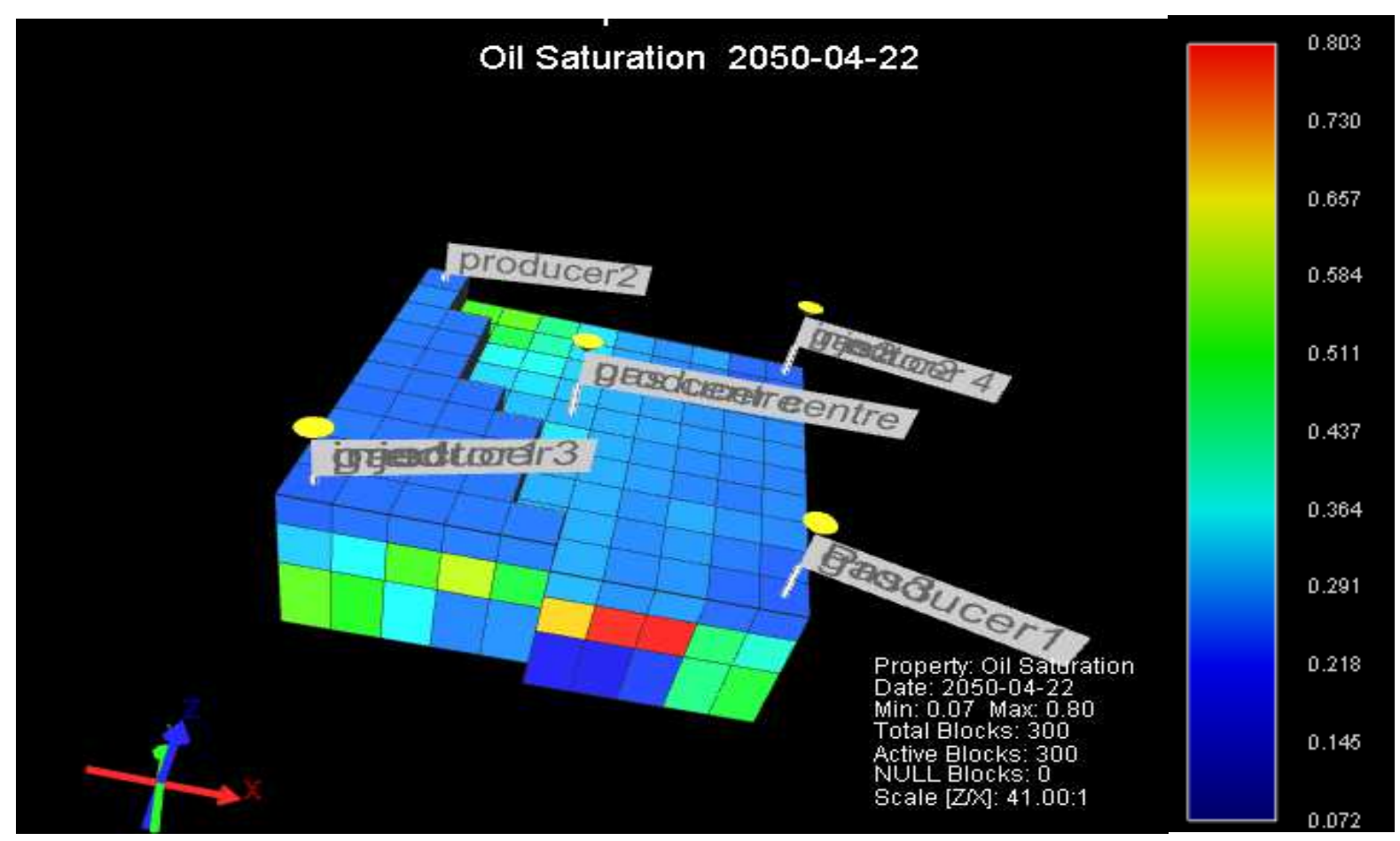

Figure 25. Oil saturation in 2050

- 2050- 2053: production by the 4 wells

We produce with all active wells in order to observe the consequence of a sudden depressurization of the field. The production has led the production of oil reserves previously stored in the layers near the injectors. A high concentration of oil has accumulated in the part of the fault close to 'producer 2'. The gas saturation is still increasing and the bubble pressure drops considerably as well as the reservoir pressure.

To determine which hypothesis is correct, we must also take a look on those graphs in Figure 26 and 27. 


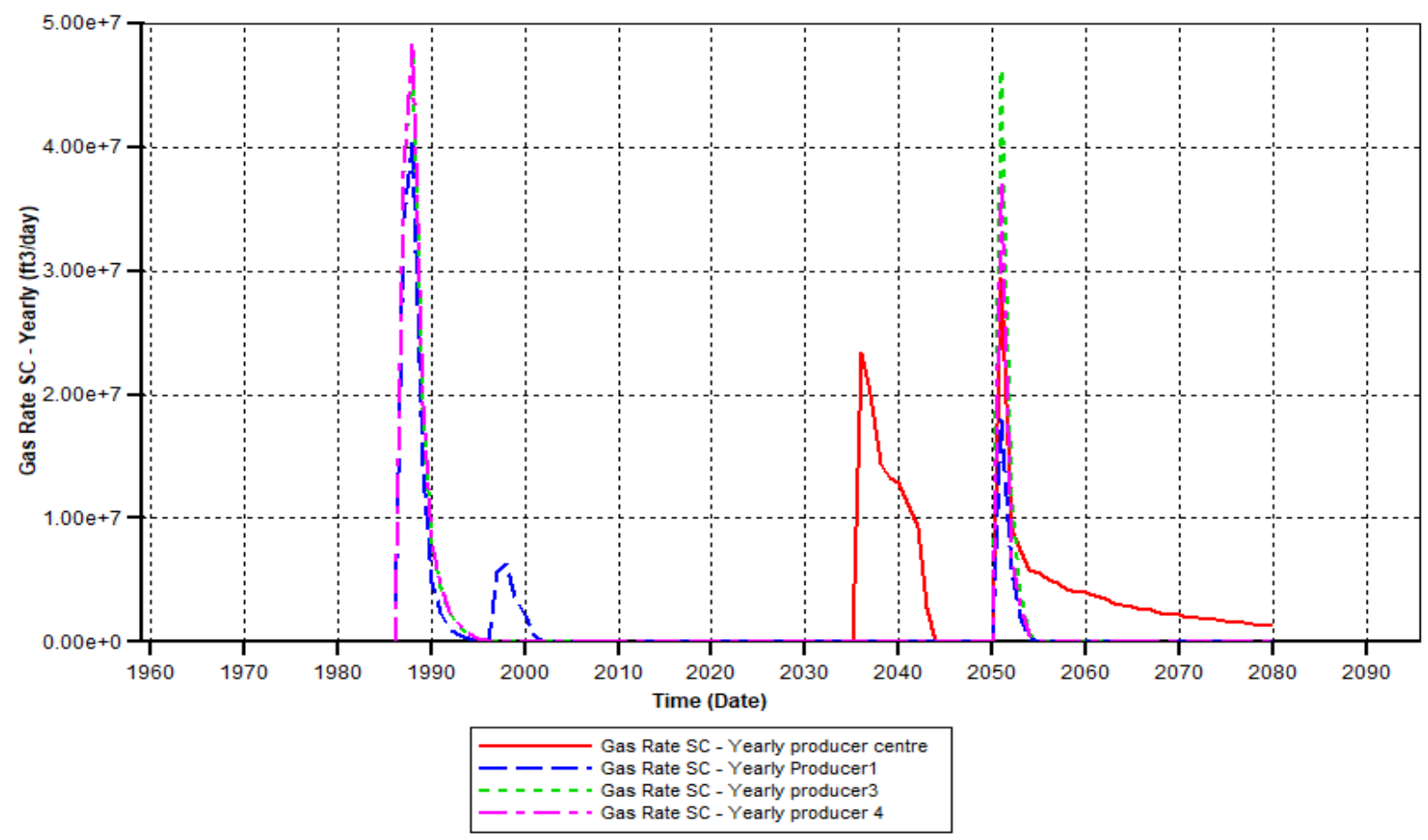

Figure 26. Gas production from wells

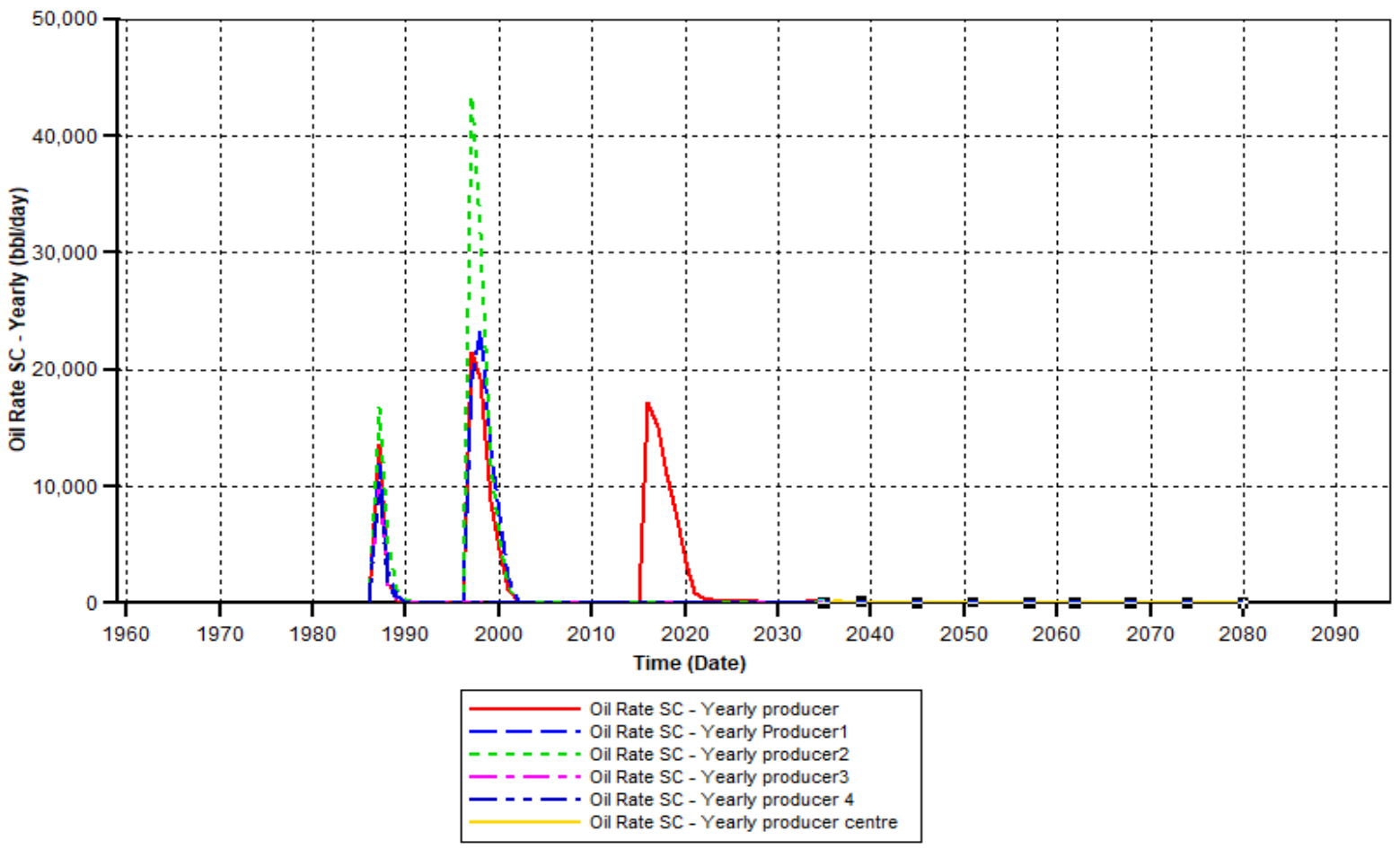

Figure 27. Oil production from wells

The gas saturation in the model at the end of the simulation is increasing but on the graphic, we can see that the gas production of the field decrease considerably. That means, the correct hypothesis is that LPG remain in liquid phase underground but the simulator consider it like oil. The gas saturation seen in the model is the LPG gas phase which can be consider like losses because his expansion in the reservoir limits the storage capacity. 


\section{Conclusion}

The simulation have allowed us to highlight the following facts about underground LPG storage:

- The gas is kept in liquid phase until the tank is depressurized;

- The mixture produced is composed of light oil, water and gas;

- The overpressure of the reservoir can increase gas production but can also damage the cap rock;

- It is better to produce at a slow rate to maintain the gas in liquid phase;

- The abandon of the storage can be cause by the damage of the reservoir structure , overproduction of water and a too much gas phase expansion;

- It is possible to stored many types of gas;

- It is preferable to inject and produce from the same well;

- To evacuate the gas phase, it is necessary to inject water in the reservoir.

\section{Conflicts of Interest / Competing Interests}

- The authors have no relevant financial or non-financial interests to disclose.

- The authors have no conflicts of interest to declare that are relevant to the content of this article.

- All authors certify that they have no affiliations with or involvement in any organization or entity with any financial interest or non-financial interest in the subject matter or materials discussed in this manuscript.

- The authors have no financial or proprietary interests in any material discussed in this article.

\section{Compliance with Ethical Standards:}

- Disclosure of potential conflicts of interest

- Research involving Human Participants and/or Animals

- Informed consent

\section{References}

Abdelaziz EL-HOSHOUDY and Saad DESOUKY, "PVT Properties of Black Crude Oil," Article, accessed 08/15/20 at https://www.intechopen.com/books/, doi:10.5772/intechopen.82278,2019.

Czolbe, P.; Kretzschmar, H.-J.: Reservoirmechanische Untersuchungen zur Gas-WasserStrömung in Gasspeichern. Teil 2- Reservoirmechanische Berechnungskonzeption zur Phasendispersion und Feldbedingungen. Zeitschrift für angewandte Geologie, Band 28 (1982) Heft 3

Kleppe, J.: Material Balance Equations. TPG4150 Reservoir Recovery Techniques 2010; Department of petroleum Engineering and Applied Sciences, Norwegian University of Science and Technology. 
Malakooti, R., \& Azin, R. (2011). The Optimization of Underground Gas Storage in a Partially Depleted Gas Reservoir. Petroleum Science and Technology, 29(8), 824836. Doi:10.1080/10916460903486742.

E. khamechchi , Amirkabir university ( Tehran polytechnic); F. rashidi, Amirkabir University of technology ( Tehran polytechnic), Simulation of Underground Natural Gas storage in Sarajeh Gas Field, Iran , SPE 106341.

A.C.LACOSTE et P.BEREST, « Stockages souterrains d'hydrocarbures : sécurité et protection de l'environnement», article, Revue française de Géotechnique, doi : 10.1051/geotech/198114b061, 1981.

GUANGCHUAN Liang and BINGQIANG Zhang, « The Dynamic Simulation of Underground Gas Storage by Computer », article, ResearchGate, DOI: 10.1109/ICCIS.2011.289, 2011.

CMG (Computer Modelling Group) General release, consulté le 20/08/2020 sur le site https://www.cmgl.ca/software ,2020. 